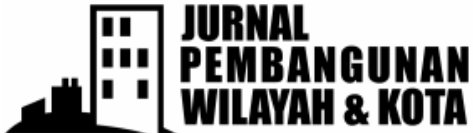

\section{Kajian Kelembagaan dalam Pengembangan Pariwisata Pantai yang Berkelanjutan}

\author{
Tendy Kuhaja ${ }^{1}$
}

Diterima : 2 Mei 2014

Disetujui : 16 Mei 2014

\begin{abstract}
Local Government Program in the development of tourism Wonokerto Beach is not maximized, but very crowded by tourists on Friday and Sunday. This raises the question of research on how to develop the existing institutional system of tourism component manager with the principles of sustainable institutions. This research uses the case study method. The analysis used is descriptive qualitative analysis. The results showed the identification of 15 stakeholders, management efforts have done, but still conducted themselves according to the level of interest and influence stakeholders. Based on the results of the study are also not found in the formal institutional Wonokerto coastal tourism development. So in order to be sustainable institutional development manager required coordination among stakeholders to achieve a common goal.
\end{abstract}

Keywords: institutional, tourism, stakeholders, sustainable

\section{ABSTRAK}

Program Pemerintah Daerah dalam upaya pengembangan pariwisata di Pantai Wonokerto memang belum maksimal, namun sangat ramai dikunjungi wisatawan pada hari jumat dan minggu. Hal tersebut menimbulkan pertanyaan penelitian mengenai bagaimana mengembangkan sistem kelembagaan eksisting pengelola komponen pariwisata dengan prinsip kelembagaan yang berkelanjutan. Penelitian ini menggunakan metode studi kasus. Analisis yang digunakan adalah analisis deskriptif kualitatif. Hasil penelitian menunjukkan dari 15 stakeholders hasil identifikasi, sudah melakukan upaya pengelolaan, namun masih dilakukan sendiri-sendiri sesuai tingkat kepentingan dan pengaruh stakeholders. Berdasarkan hasil penelitian juga tidak ditemukan kelembagaan formal dalam pengembangan pariwisata pesisir Pantai Wonokerto. Sehingga agar pengembangan kelembagaan pengelola dapat berkelanjutan diperlukan koordinasi antar stakeholder untuk mencapai tujuan bersama.

Kata kunci: kelembagaan, pariwisata, stakeholders, berkelanjutan

\footnotetext{
${ }^{1}$ Kementerian Kelautan dan Perikanan Republik Indonesia

Kontak Penulis: tendykuhaja@kkp.go.id
} 


\section{PENDAHULUAN}

Pariwisata dalam beberapa dekade terakhir merupakan suatu sektor yang sangat penting dalam pembangunan ekonomi bangsa-bangsa di dunia. Sektor pariwisata diharapkan menjadi industri atau sektor penting yang dapat diandalkan Pemerintah ke depan untuk menjadi pilar utama pembangunan ekonomi nasional. Sejak era otonomi daerah, memberikan kewenangan kepada daerah untuk melakukan perencanaan, pengembangan dan pengelolaan pariwisata di daerah. Proses dan mekanisme pengambilan keputusan menjadi lebih sederhana dan cepat. Peluang untuk melibatkan masyarakat lokal dalam proses pengembangan pariwisata juga menjadi lebih terbuka. Kesempatan tersebut juga berlaku untuk Kabupaten Pekalongan. Dalam meningkatkan pertumbuhan ekonomi, pemerintah daerah berusaha menggali potensi wisata yang ada. Selain Industri batik yang sedang berkembang, Kabupaten Pekalongan juga memiliki banyak obyek dan daya tarik wisata alam sebagai modal dalam pengembangan pariwisata. Potensi daya tarik wisata yang ada antara lain berupa keaneka ragaman hayati (hutan lindung), keunikan dan keaslian budaya tradisional dan keindahan bentang alam (pantai, pegunungan, danau, air terjun). Salah satu pantai di Kabupaten Pekalongan yang menjadi obyek dan daya tarik wisata adalah Pantai Wonokerto. Pantai ini digunakan untuk tempat berwisata oleh masyarakat sekitar Pekalongan. Pantai tersebut selalu dikunjungi oleh masyarakat setiap harinya dengan peningkatan jumlah pengunjung secara signifikan pada hari Jumat sore dan sepanjang hari Minggu.

Pada hakekatnya upaya pengembangan pariwisata selain merupakan tanggungjawab pemerintah, masyarakat dan pihak swasta juga diharapkan turut berpartisipasi aktif dalam perencanaan, pelaksanaan dan pengendalian. Karena pengembangan pariwisata merupakan upaya yang sangat kompleks yang perlu melibatkan semua stakeholders. Dalam pengelolaan wisata Pantai Wonokerto agar berkelanjutan diperlukan kelembagaan yang baik dan berfungsi serta berperan aktif dalam pengelolaan pariwisata. Kelembagaan tersebut mencangkup kelembagaan informal yang dibentuk oleh masyarakat sendiri dan kelembagaan formal yang datang dari pemerintahan. Menurut Aulia (2010) kesinergisan antara kelembagaan formal dan informal dapat menjadikan pariwisata menjadi lebih terorganisir dengan baik dan meminimalisir dampak negatif dari pariwisata. Kelembagaan yang baik dalam sistem pengelolaan tidak lupa didukung oleh sosialisasi dan kontrol yang baik sehingga kelembagaan dapat berjalan efektif.

Dalam dokumen rencana strategis pengembangan pariwisata pesisir oleh Dinas Pemuda, Olahraga dan Pariwisata Kabupaten Pekalongan, yang menjadi prioritas utama bukan pantai Wonokerto melainkan pantai Depok. Hal tersebut menjadikan minimnya Program Pemerintah Daerah dalam upaya pengembangan pariwisata di Pantai Wonokerto. Salah satu permasalahan yang terjadi adalah tidak adanya kelembagaan formal yang bertanggungjawab terhadap keberlanjutan pengelolaan pariwisata di Pantai Wonokerto, seperti diutarakan oleh pihak Kecamatan Wonokerto sebagai berikut:

"karena sementara yang saya tau dari lembaga resmi dalam hal ini pemerintah belum menggerakkan, masyarakat sudah menggerakkan ke arah sana contohnya hari jum'at dan hari minggu, itu pesisir ini penuh dengan terutama dengan anak-anak muda."

Tanpa upaya pengelolaan dikhawatirkan dapat menghambat pembangunan pariwisata yang berkelanjutan. Selain itu juga akan menimbulkan dampak negatif dari pariwisata itu sendiri, selain faktor alam yang mengancam pengembangan pariwisata di kawasan tersebut. Sehingga menimbulkan pertanyaan penelitian mengenai bagaimana mengembangkan sistem 
kelembagaan eksisting pengelola komponen pariwisata dengan prinsip kelembagaan yang berkelanjutan.

\section{METODE PENELITIAN}

Penelitian ini menggunakan metode studi kasus dengan entitas tunggal atau fenomena ("kasus") dari suatu masa tertentu dan aktivitas (berupa program, kejadian, proses, institusi atau kelompok sosial tertentu) serta mengumpulkan detail informasi dengan menggunakan berbagai prosedur pengumpulan data selama kasus itu terjadi. Yin (2012) menyatakan bahwa tujuan penelitian studi kasus tidak sekedar untuk menjelaskan seperti apa obyek yang diteliti, tetapi untuk menjelaskan bagaimana keberadaan dan mengapa kasus tersebut dapat terjadi.

Teknik pengumpulan data dalam penelitian ini yaitu dengan observasi/pengamatan langsung, wawancara, kajian literatur dan dokumentasi. Data yang sudah didapatkan kemudian diolah dengan cara di reduksi dan dilakukan pengkodean wawancara. Reduksi data digunakan untuk membuang/mengurangi data-data dari hasil wawancara yang akan digunakan dalam proses analisis, mengingat data yang diperoleh sangat banyak. Pengkodean Wawancara dilakukan dengan tujuan untuk mengklasifikasikan jawaban-jawaban hasil wawancara informan menurut jenis pertanyaannya.

Teknik sampling yang digunakan dalam memilih informan yang diwawancarai adalah dengan menggunakan purposive sampling yaitu teknik penentuan sampel dengan pertimbangan bahwa informan adalah pelaku, baik individu maupun instansi/lembaga yang mengerti permasalahan dan dapat memberikan informasi yang akurat. Penetepan informan dalam konteks ini bukan ditentukan oleh pemikiran bahwa responden harus representatif terhadap populasinya, melainkan responden harus representatif dalam memberikan informasi yang diperlukan sesuai dengan fokus dan tujuan penelitian (Siregar 2011). Wawancara dilakukan secara semi terstruktur dengan menggunakan panduan wawancara kepada informan kunci (Key informan) dari masing-masing stakeholders. Wawancara dengan informan kunci bertujuan untuk mendapatkan informasi khusus mengenai suatu topik (Mikkelsen 2003). Snowball sampling digunakan sebagai alat dalam pengambilan sampel, yaitu teknik penentuan sampel yang mula-mula jumlahnya kecil, kemudian membesar. Ibarat bola salju yang menggelinding yang lama-lama menjadi besar (Sugiono, 2009).

Analisis deskriptif kualitatif digunakan untuk melihat kondisi eksisting kelembagaan pengelola komponen pariwisata berdasarkan data potensi komponen pariwisata dan keterlibatan stakeholders yang ada, sehingga diketahui arahan pegembangan sistem kelembagaan eksisting pengelola komponen pariwisata dengan prinsip kelembagaan yang berkelanjutan. Teknik analisis deskriptif kualitatif merupakan suatu teknik analisis untuk membuat gambaran mengenai suatu fenomena, menerangkan hubungan, menguji hipotesa serta mendapatkan implikasi dari suatu masalah yang ingin diteliti (Nazir, 1988: 64).

\section{GAMBARAN UMUM}

Kabupaten Pekalongan dengan Kota Kajen sebagai Ibukota pusat pemerintahan, terletak pada 6" 83' 7" - 23' LS dan 109" 49' - 109" 78' BT. Wilayah Kabupaten Pekalongan ini terletak di pantai utara Pulau Jawa yang memanjang dari Pantai Utara Laut Jawa ke bagian Selatan, dengan luas wilayah meliputi $\pm 836,13 \mathrm{Km}^{2}$. Secara topografi Kabupaten Pekalongan terdiri atas 
wilayah pantai, wilayah dataran rendah dan wilayah pegunungan dengan ketinggian $4 \mathrm{dpl}$ s/d $1.294 \mathrm{dpl}$ (di atas permukaan air laut). Wilayah pantai berada di sebagian kecil di bagian Utara yang berbatasan langsung dengan Laut Jawa. Wilayah dataran rendah berada di bagian barat, tengah dan timur Kabupaten Pekalongan. Wilayah pegunungan berada di bagian Selatan. Sedangkan menurut topografi desa terdapat 58 desa/kelurahan sebanyak 20\% yang merupakan desa berdataran tinggi atau pegunungan dan sebanyak $80 \%$ atau 225 desa/kelurahan yang berada didataran rendah atau pusat keramaian. Bagian utara Kabupaten Pekalongan merupakan dataran rendah; sedang di bagian selatan berupa pegunungan, bagian dari rangkaian Dataran Tinggi Dieng.

\section{KAJIAN TEORI}

\section{Potensi Komponen Pariwisata Pantai Wonokerto}

1. Atraksi

Keindahan bentang alam Pantai Wonokerto dengan kondisi topografinya yang landai merupakan suatu potensi yang mendukung pengembangan pariwisata. Deburan ombak yang tidak tertalu besar memungkinkan wisatawan untuk melakukan kegiatan air. Hamparan pantai yang luas juga dapat dijadikan tempat bermain bola oleh pengunjung. Selain itu, keberadaan Tempat Pelelangan Ikan (TPI), tambak, mangrove dan kebun melati juga mempunyai daya tarik wisata tersendiri. Setelah beraktifitas di pantai, wisatawan dapat melihat suasana lain di sekitar tambak dengan perpaduan mangrove serta beberapa kebun melati. Sebelum meninggalkan kawasan, wisatawan dapat membeli ikan segar langsung dari nelayan yang mendaratkan hasil tangkapannya di TPI. Ditambah dengan adanya atraksi budaya Nyadran yang setiap tahun diadakan dan akan selalu dilestarikan. Nyadran merupakan pergelaran syukuran masyarakat nelayan atas rejeki yang sudah didapatkan selama setahun. Selain Nyadran ada juga kegiatan syawalan yang dikemas secara swadaya oleh masyarakat setempat dengan menghadirkan hiburan-hiburan.

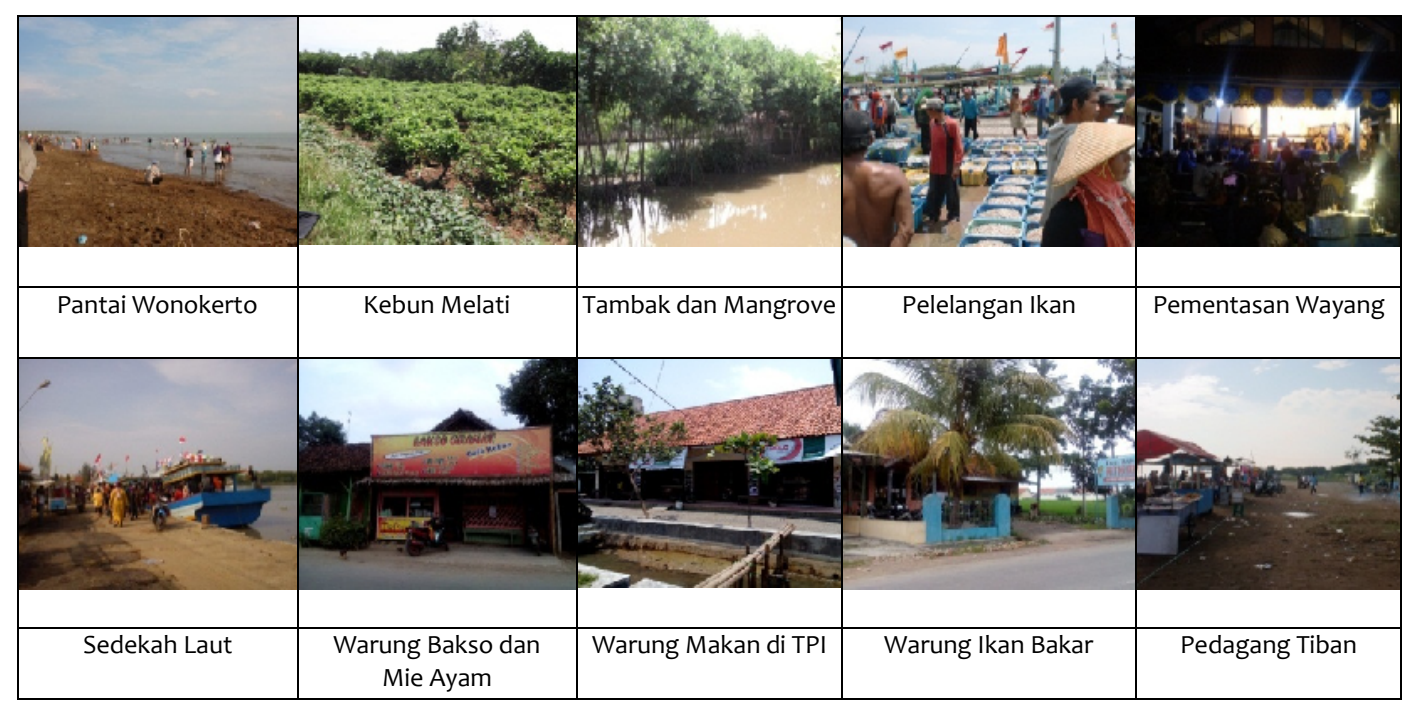

Sumber: Survey Lapangan 2013-2014

GAMBAR 1 KONDISI ATRAKSI DAN AMENITY 


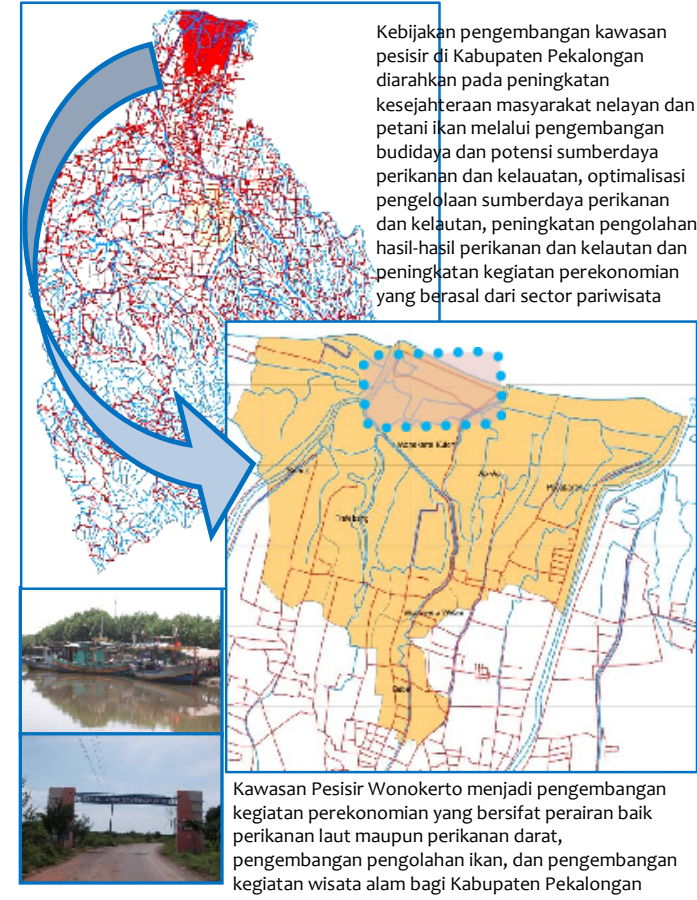

Sumber : Hasil Analisis, 2013

\section{GAMBAR 2 \\ KONSTELASI KAWASAN PESISIR WONOKERTO TERHADAP KABUPATEN PEKALONGAN}

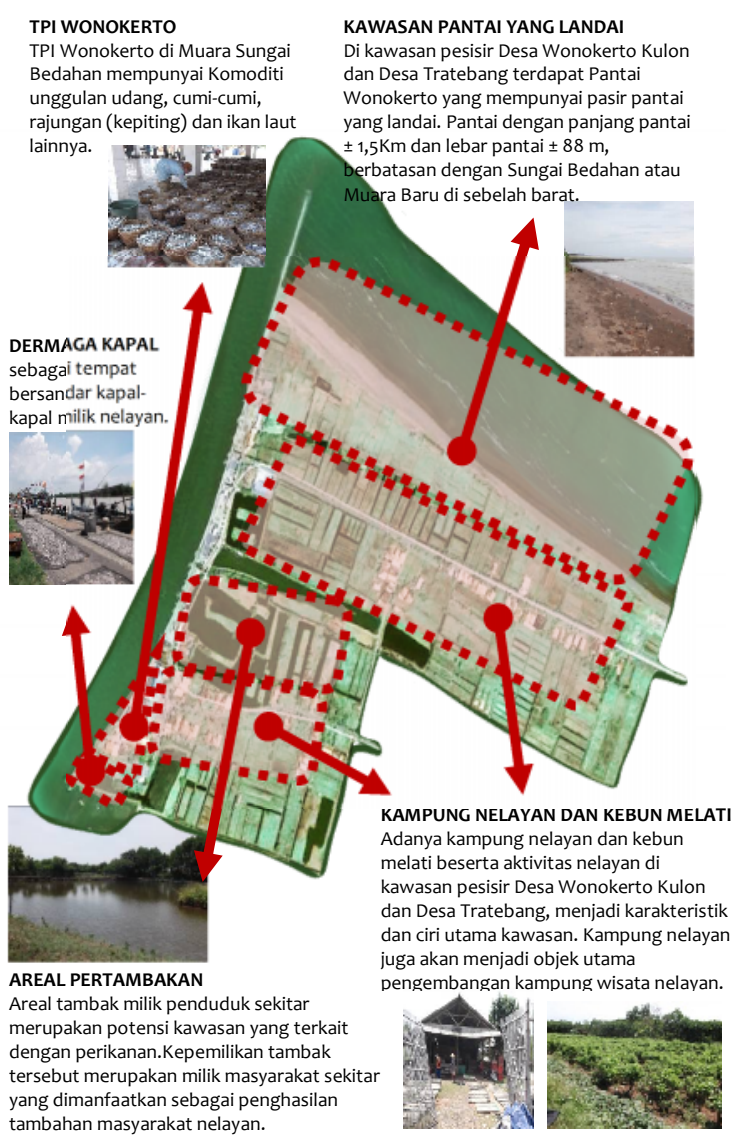

Sumber : Hasil Analisis, 2013

\section{GAMBAR 3 \\ POTENSI KAWASAN PESISIR PANTAI WONOKERTO KABUPATEN PEKALONGAN}

2. Amenity

Dalam pemenuhan kebutuhan Amenity/Pelayanan pariwisata di pesisir Pantai Wonokerto, jenis pelayanan yang didapatkan oleh wisatawan masih sangat terbatas. Di sekitar obyek wisata pantai masih belum tersedia rumah makan. Hanya ada di sekitar TPI dan dikelola secara pribadi oleh pengusaha lokal. Untuk dapat menemukan berbagai variasi jenis makanan seperti ikan bakar, bakso, mie ayam, wisatawan hanya bisa menemukan rumah makan di pusat Kecamatan Wonokerto yang mengarah ke Wiradesa. Namun pada setiap Jumat sore dan sepanjang hari Minggu, wisatawan akan sangat mudah menemukan kios makanan ringan dan minuman di sekitar pantai. Banyak pedagang yang datang berjualan di lokasi wisata.

3. Aksesibilitas

Aksesibilitas untuk mencapai lokasi pantai masih belum tersedia angkutan umum yang beroperasi secara reguler, sehingga harus menggunakan angkutan pribadi. Hanya tersedia angkutan becak dan dokar yang "ngetem" di simpang jalan wiradesa menuju Wonokerto. Namun keberadaan dokar dan becak semakin sedikit. Hal tersebut dikarenakan jumlah penumpangnya yang semakin berkurang. Penggunaan kendaraan bermotor terutama roda 
dua dianggap lebih efektif dibandingkan dengan menggunakan dokar dan becak. Selain itu juga terdapat kereta kelinci sebagai alternatif hiburan bagi wisatawan yang datang ke pesisir Pantai Wonokerto. Berbeda dengan dokar, keberadaan jumlah kereta kelinci semakin bertambah. Untuk dapat beroperasi di jalan, dokar dan kereta kelinci juga tidak memerlukan ijin khusus. Dokar dan kereta kelinci juga tidak mempunyai trayek yang resmi. Kebanyakan dari mereka beroperasi di jalan tergantung dari tujuan penumpangnya.

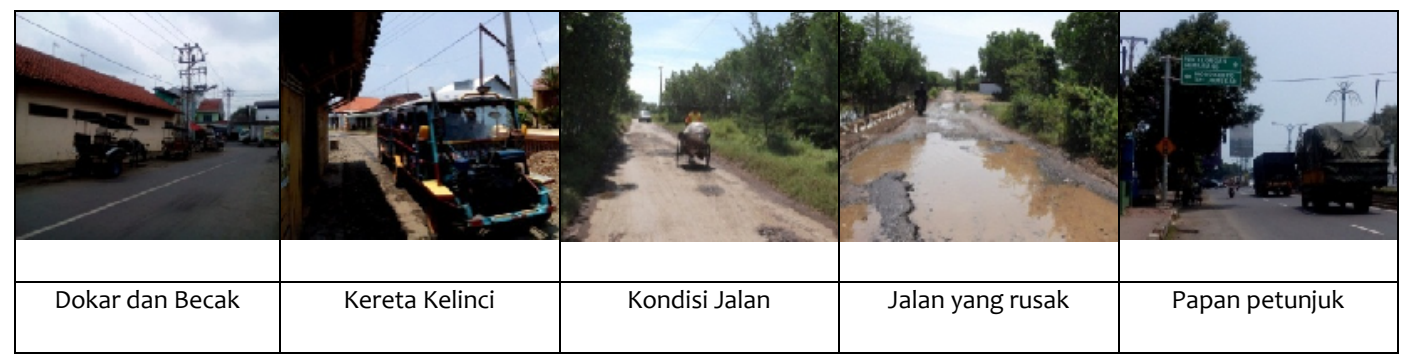

Sumber: Survey Lapangan 2013-2014

\section{GAMBAR 4 \\ KONDISI AKSESIBILITAS DAN PROMOSI}

Kondisi jalan menuju kawasan pesisir Wonokerto dapat dikatakan cukup baik, karena sudah tersedia jalan beraspal dengan dua jalur. Namun kondisinya sekarang sudah rusak oleh banjir dan rob. Menurut dokumen RTRW, jalan yang menuju lokasi wisata merupakan jalan Kabupaten. Namun belum ada tanggapan positif dari Pemerintah Daerah. Sebagai upaya agar kerusakan tidak semakin parah serta guna memperlancar distribusi ikan yang berasala dari TPI, maka sejumlah warga dan nelayan serta para bakul ikan ditarik iuran guna menguruk beberapa jalan yang rusak. Setiap orang yaitu warga yang memiliki tambak di sepanjang jalan dan para bakul ikan yang setiap hari pergi ke TPI untuk transaksi ikan dibebani sejumlah nilai rupiah sebagai kompensasi dari perbaikan jalan yang ada.

4. Promosi

Salah satu upaya pengembangan pariwisata adalah dengan melakukan promosi dan penyebarluasan informasi. Pada skala yang paling kecil, upaya promosi yang bisa dilakukan adalah oleh wisatawan itu sendiri. Pengalaman menyenangkan yang didapatkan selama beraktifitas wisata kemudian menyebar ke masyarakat lain. Sehingga lokasi wisata yang didatangi tersebut lebih dikenal oleh masyarakat luas. Pembuatan papan arah menuju obyek wisata Pantai Wonokerto di jalan utama pantai utara jawa di Kabupaten Pekalongan memandu wisatawan menuju obyek wisata. Namun upaya promosi dan penyebarluasan informasi dengan skala yang lebih besar masih minim dilakukan, sehingga pengembangan pariwisata pantai Wonokerto hanya berkembang dengan skala lokal Kabupaten Pekalongan.

Khusus untuk acara nyadran dan syawalan, promosi sudah dilakukan lebih baik. Sebagai infomasi kepada masyarakat luas, upaya promosi dilakukan dengan membuat spanduk besar di tempat-tempat keramaian seperti Pasar Wiradesa. Selain itu juga dilakukan penyebaran pamflet di jalan raya. Media elektronik seperti stasiun radio juga sudah digunakan sebagai sarana promosi jika akan mendatangkan artis ibukota. Seperti Radio Damashinta dan Radio Kota Batik. 


\section{Kelembagaan Pariwisata Pesisir yang Berkelanjutan}

Pariwisata adalah perjalanan dari suatu tempat ke tempat lain, bersifat sementara, dilakukan perorang atau kelompok, sebagai usaha mencari keseimbangan atau keserasian dan kebahagian dengan lingkungan hidup dalam dimensi sosial budaya, alam dan ilmu (Kodhyat dalam Spillane, 1994:21). Sedangkan menurut Wahab (1992:5) dari definisi yang dikemukakan para pakar tersebut dapat diambil unsur-unsur dari pariwisata adalah: adanya kegiatan mengunjungi suatu tempat, bersifat sementara, ada sesuatu yang ingin dilihat atau dinikmati, dilakukan perseorangan atau sekelompok orang, mencari kesenangan/kebahagiaan, adanya fasilitas ditempat wisata. Jenis-jenis Pelaku pariwisata yang terlibat di dalam pasar pariwisata antara lain wisatawan, industri pariwisata, pendukung jasa pariwisata, pemerintah, masyarakat lokal danlembaga swadaya masyarakat/LSM (Damanik dan Weber, 2006). Menurut Gunn (1993) komponen pariwisata meliputi atraksi, amenity, aksesibilitas, promosi dan informasi.

Wilayah pesisir adalah daerah pertemuan antara darat dan laut, dengan batas ke arah darat meliputi bagian daratan, baik kering maupun terendam air yang masih mendapat pengaruh sifat-sifat laut, sedangkan batas wilayah pesisir ke arah laut dimana ciri-ciri perairan ini masih dipengaruhi oleh proses alami yang terjadi di darat (Bengen, 2002). Sedangkan menurut Undang Undang Nomor 27 Tahun 2007, disebutkan bahwa Wilayah Pesisir adalah daerah peralihan antara ekosistem darat dan laut yang dipengaruhi oleh perubahan di darat dan laut. Batas ke arah darat mencakup wilayah administrasi kecamatan. Kewenangan daerah kabupaten/kota ke arah laut paling jauh 4 mil diukur dari garis pantai ke arah laut lepas.

Pengertian dari kata kelembagaan adalah suatu sistem badan sosial atau organisasi yang melakukan suatu usaha untuk mencapai tujuan tertentu (Pusat Bahasa, 1997). Kelembagaan adalah suatu tatanan dan pola hubungan antara anggota masyarakat atau organisasi yang saling mengikat yang dapat menentukan bentuk hubungan antar manusia atau antara organisasi yang diwadahi dalam suatu organisasi atau jaringan dan ditentukan oleh faktor-faktor pembatas dan pengikat berupa norma, kode etik aturan formal maupun informal untuk pengendalian prilaku sosial serta insentif untuk bekerjasama dan mencapai tujuan bersama (Djogo, et.al., 2003).

\section{ANALISIS}

\section{Analisis Kelembagaan Eksisting Pengelola Pariwisata Pantai Wonokerto}

Hasil dari identifikasi diperoleh 15 (lima belas) stakeholders yang terlibat dalam pengembangan kawasan wisata pesisir pantai Wonokerto, yaitu: Badan Perencanaan Pembangunan Daerah (Bappeda), Dinas Pekerjaan Umum (DPU), Dinas Kelautan, Perikanan dan Peternakan (DKPP), Dinas Pemuda, Olahraga dan Pariwisata (Dinporapar), UPTD Pelabuhan Perikanan Pantai Dinas Perikanan dan Kelautan Provinsi Jawa Tengah, Kantor Pelabuhan Pekalongan Wilker Wiradesa Dirjen Hubla Kemenhub, Kecamatan Wonokerto, Desa Wonokerto Kulon, Desa Tratebang, KUD Mino Soyo, Pengusaha Lokal, Kelompok Nelayan (Fisherman's), HNSI Kabupaten Pekalongan, masyarakat setempat dan wisatawan.

1. Kelembagaan Pengelola Atraksi

Bukti keseriusan pemerintah daerah Kabupaten Pekalongan dalam pengembangan pariwisata pesisir Pantai Wonokerto adalah dengan disusunnya Dokumen Masterplan Khusus Pariwisata Kawasan Wonokerto. Dalam dokumen tersebut dijabarkan mengenai rencana pengembangan pariwisata di kawasan Wonokerto. Dokumen tersebut disusun dengan dimotori oleh Dinas Pemuda, Olahraga dan Pariwisata. Pembuatan dokumen tersebut diinisiasi karena pada saat itu ada investor yang akan bekerjasama dengan 
pemerintah daerah dalam hal ini Dinporapar untuk mengembangkan pariwisata di pesisir Pantai Wonokerto. Investor dari Jakarta tersebut tertarik dengan pengembangan secara terpadu mulai dari sungai pencongan hingga ke pantai Wonokerto menjadi suatu kawasan khusus pariwisata yang dikemas dengan berbagai kegiatan wisata. Dalam perjalanannya, setelah dokumen tersebut dibuat, Dinporapar dan investor tersebut bersama dengan KDU "Mino Soyo" melakukan langkah awal untuk persiapan pengembangan pariwisata. Namun menurut ketua KUD, terkendala oleh pembebasan lahan yang sebenarnya milik pemerintah tetapi sudah sekian lama dimanfaatkan oleh masyarakat sebagai kebun melati maupun tambak.

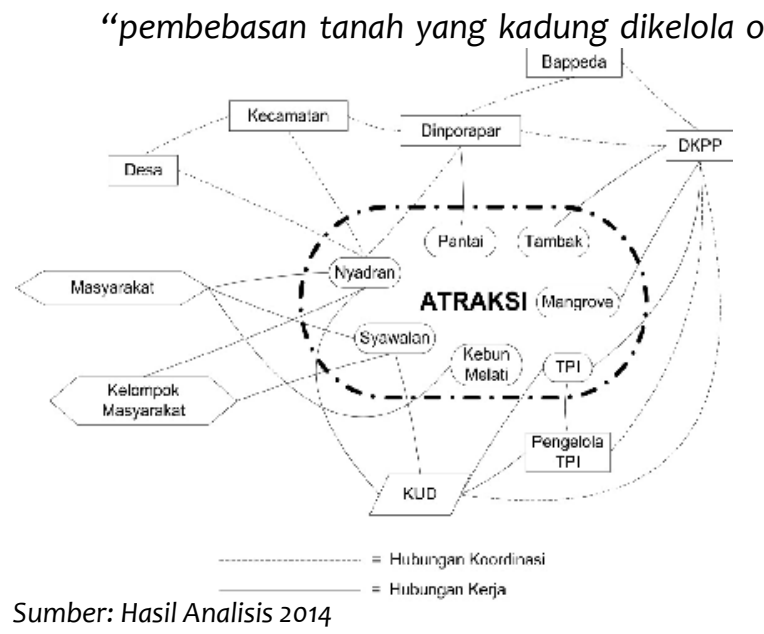

GAMBAR 5

POLA HUBUNGAN PENGELOLAAN ATRAKSI masyarakat, itu tanah Negara tapi pada waktu itu ada tim yang di bentuk masyarakat, permeter perseginya mau di hargai berapa. Seribu berapa atau sepuluh ribu berapa saya lupa. Tetapi pada waktu itu tidak terjadi kesepakatan." (Ke/S1/11)

Setelah gagalnya negosiasi dengan pihak investor ditambah lagi dengan fenomena banjir dan rob yang mengancam kawasan pesisir menjadikan dokumen masterplan tersebut hanya sebuah produk perencanaan yang tidak dapat di implementasikan. Fenomena banjir dan rob menjadi permasalahan baru dalam pengembangan pesisir pantai wonokerto. Fenomena banjir dan rob memang dewasa ini sangat mengganggu pembangunan di seluruh wilayah pesisir, terutama di pesisir pantai utara Jawa. Hal tersebut juga mengancam pesisir di Kabupaten Pekalongan. Kondisi tersebut semakin mengendorkan niat dari Dinporapar dan investor tersebut untuk berinvestasi di pesisir Kabupaten Pekalongan. Hal paling utama yang ditakutkan adalah besarnya nilai investasi yang digelontorkan dikhawatirkan tidak sebanding dengan ancaman kegagalan program oleh fenomena banjir dan rob yang ada di kawasan pesisir. Sehingga rencana investor tersebut sampai saat ini tidak ada kelanjutannya, seperti diungkapkan oleh salah satu kepala bidang di Dinporapar sebagai berikut:

"bahwa di pantai itukan semakin kesini itukan semakin naik permukaan airnya, sehingga akan menjadi rob... Tapi kan kalo diusulkan ke arah itu kan kita ketakutan. Termasuk kan untuk investor juga kalau untuk pengembangan kan bingung. Dikhawatirkan untuk sekian tahun yang akan datang kena." (Ke/P3/06)

Meskipun demikian, upaya Pemerintah Daerah Kabupaten Pekalongan tidak berhenti di situ saja. Pemerintah daerah tetap konsisten dalam pengembangan kawasan pesisir pantai Wonokerto yang keberadaannya tidak terlepas dari adanya bencana banjir rob sebagai akibat dari adanya perubahan iklim (climate change). Oleh karena itu disusunlah Dokumen Adaptasi Penanganan Rob Kawasan Wonokerto yang di tangani oleh Badan Perencanaan dan Pembangunan Daerah (BAPPEDA) Kabupaten Pekalongan. Dalam dokumen tersebut dijabarkan mengenai rencana-rencana strategis penanganan rob, prioritas penanganan rob, instansi terkait serta dukungan pendanaannya. Sehingga atraksi wisata yang ada di 
pesisir Pantai Wonokerto dapat terjaga. Untuk wilayah Wonokerto prioritas penanganan rob dilakukan dengan pembangunan tanggul pada sungai wonokerto dan sungai sudetan Wonokerto, pembangunan pintu air dan penanaman mangrove.

Selain bentangan alam tersebut atraksi lain yang menjadi daya tarik wisatawan adalah adanya dermaga, TPI dan perkampungan nelayan. Dermaga, TPI dan perkampungan nelayan sangat terkait dengan pemanfaatan sumberdaya pesisir dan laut. Dermaga merupakan sarana pendaratan kapal, TPI merupakan tempat pelelangan hasil laut dan perkampungan nelayan merupakan subyek/pemanfaat langsung dari sumberdaya pesisir dan laut yang ada. Melalui Perda No. 16 tahun 2009 tentang Rencana Pengelolaan Wilayah Pesisir dan Perda No. 17 tahun 2009 tentang Rencana Zonasi Wilayah Pesisir yang penyusunannya dimotori oleh Dinas Kelautan, Perikanan dan Peternakan Kabupaten Pekalongan, merupakan pedoman dalam pengelolaan dan pemanfaatan kawasan pesisir pantai Wonokerto. Sehingga aktifitas pemanfaatan sumberdaya pesisir dan laut dapat dikendalikan secara lestari. Kelestarian tersebut memberikan implikasi kepada atraksi wisata pesisir yang berkelanjutan.

Atraksi lain yang ada di Kawasan Pesisir Pantai Wonokerto adalah pergelaran upacara "Nyadran" dan "Syawalan". Nyadran merupakan serangkaian acara sebagai ungkapan rasa syukur terhadap pemanfaatan hasil laut.Atraksi tersebut selalu mengundang banyak penonton. Yang menarik dari kegiatan ini adalah pendanaannya yang sepenuhnya berasal dari masyarakat. Masyarakat yang berpartisipasi adalah masyarakat yang memanfaatkan hasil laut sebagai sumber penghidupan mereka seperti masyarakat nelayan, bakul ikan dan pemilik kapal. Kegiatan tersebut juga langsung dikelola oleh masyarakat. Dalam pelaksanaan kegiatan tersebut di dampingi oleh KUD "Mino Soyo". Pergelaran nyadran dalam pelaksanaan acaranya selalu mengundang jajaran instansi pemerintahan Kabupaten Pekalongan sebagai undangannya. Bahkan beberapa kali dihadiri oleh pemimpin daerah/bupati, seperti kata camat Wonokerto sebagai berikut:

"Jadi sementara ini anggaran dari swadana masyarakat nanti bagi pemilik kapal itu berapa atau kapal yang mau masuk TPI di potong berapa itu sesuai denga kesepakatan, jadi nanti kan di jumlah berapa kapal yang ada di wonokerto, setiap kapal berapa karena kapal disini jenis alat tangkapnya berbeda. Jadi kalo alat tangkapnya yang agak besar iurannya lebih besar kan gitu, nanti di jumlah, yang tau antara KUD dan TPI. TPI kan tau jumlah nelayan dan kapal berapa atau KUD juga tau, karena kebetulan itu kan KUD mina ya dan yang aktif berapa. Kurang kebihnya gitu."( Ke/P5/50)

Kegiatan lain yang selalu rutin dilaksanakan setiap tahun adalah Syawalan. Syawalan merupakan kegiatan hiburan berupa pertujukan musik, yang pendanaan dan pelaksananya juga berasal dari masyarakat itu sendiri. Berbeda dengan Nyadran yang dilaksanakan secara bersama-sama, Syawalan dilaksanakan oleh masing-masing kelompok masyarakat nelayan. Kelompok masyarakat nelayan terdiri dari para nahkoda dan ABK yang bertempat tinggal berdekatan. Tergabung dalam satu gang atau satu dusun membentuk satu kelompok tersendiri. Kegiatan pertunjukan musik terakhir dilakukan oleh sebanyak 40 kelompok nelayan. Masing-masing kelompok mendatangkan "artis" sesuai dengan kemampuan budget yang ada. Dari hanya sekedar orkes tunggal hingga mendatangkan artis dari ibukota seperti "evie tamala" dan "boomerang". Hal tersebut dikatakan oleh ketua kelompok nelayan sebagai berikut: 


\begin{abstract}
"Nah kemarin hari raya kalo ga salah kurang lebih ada sekitar 40 pertunjukan, pertunjukan itu rentang waktunya sekitar setengah bulan. Kadang-kadang yang satu malam itu ada 2 sampai 3 pertunjukan, tapi memang acara yang buget nya besar cuman Satu."(Ke/M1/02)

"iya, panggilnya itu artis-artis. Kemarin ada efitamala ada elfi sukaisih, padahal satu artis itu 50 sampai 55 juta, jadi anggaran untuk satu kegiatan yang lain-lain ada yang habis 150, ada yang habis $130 . . . . .$. Ga ada yang berantem, kemarin boomerang, luar biasa pekalongan ga ada keributan sama sekali."(Ke/M1/04)
\end{abstract}

Dari uraian di atas dapat digambarkan bahwa dalam pengelolaan atraksi, tidak hanya instansi pemerintah yang melakukan. Namun dari pihak swasta dan masyarakat sudah berperan aktif dalam pengelolaan atraksi yang ada.

2. Kelembagaan Pengelola Amenity Kebijakan Pemerintah Daerah untuk memberikan pelayanan (Amenity) dalam pengembangan pariwisata pesisir Pantai Wonokerto dilakukan dengan memberikan kesempatan seluas-luasnya kepada pengusaha untuk mendirikan usaha di bidang pariwisata di Kabupaten Pekalongan. Diharapkan pengusaha tersebut dapat membantu ketersediaan kebutuhan wisatawan seperti perhotelan, rumah makan/restoran, Biro/Agen perjalanan wisata, pusat seni dan kerajinan dan sebagainya. Pedoman pengembangan usaha tersebut dilegitimasi dengan dilahirkannya beberapa Peraturan

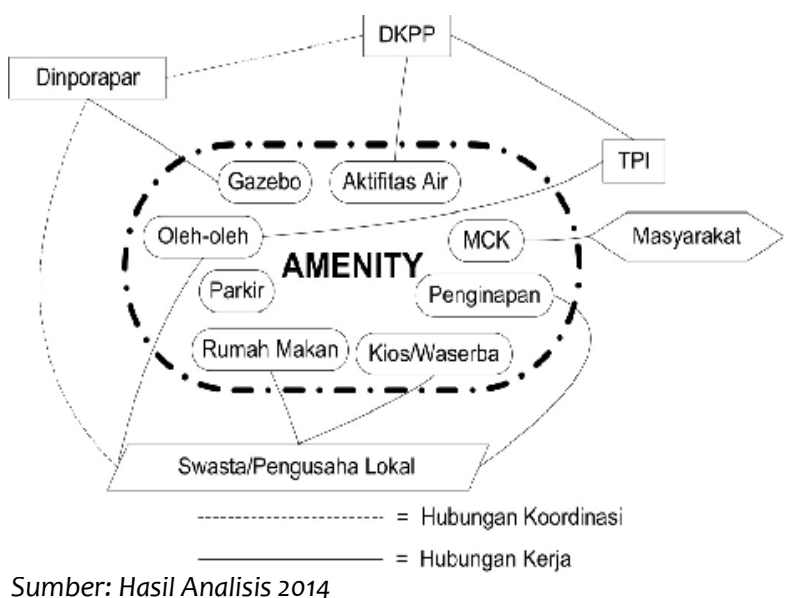
Sumber: Hasil Analisis 2014

\section{GAMBAR 6 POLA HUBUNGAN PENGELOLAAN AMENITY} Daerah seperti Peraturan mengenai Ijin Usaha Pariwisata, Retribusi Daerah, Retribusi ljin Usaha Pariwisata. Selain itu bagi para wisatawan juga dikenakan tarif retribusi sesuai dengan Peraturan Daerah No. 11 Tahun 2008 tentang Retribusi Tempat Rekreasi dan Olah Raga.

Pengelolaan Amenity yang dilakukan oleh pemerintah daerah masih sangat minim dalam memberikan pelayanan kepada wisatawan. Pemerintah Daerah hanya melakukan pembangunan gazebo dan gapura masuk menuju kawasan pantai tanpa penarikan retribusi kepada wisatawan. Pembangunan dermaga sebagai sarana kegiatan air seperti pendaratan perahu wisata juga masih disatukan dengan dermaga nelayan. Sektor swasta juga masih berjalan secara parsial. Belum ada koordinasi dalam pengelolaan bersama. Penyediaan fasilitas pariwisata masih berjalan sendiri-sendiri sesuai dengan ketersediaan pendanaan dan kepentingan masing-masing stakeholders yang ada. Pelayanan rumah makan dan kios atau warung serba ada (waserba) masih dikelola sendiri oleh swasta hanya karena faktor ekonomi. Fasilitas parkir juga tidak ada pengelolaannya di semua lokasi pariwisata. Setelah mandi di pantai, banyak wisatawan terpaksa basah-basahan sampai ke rumah. Hanya beberapa yang menumpang penduduk setempat untuk melakukan bilas mandi. Karena sarana MCK hanya terbatas di sekitar TPI dan dikelola oleh masyarakat setempat. Oleh-oleh yang bisa di bawa pulang wisatawan hanya berupa ikan hasil 
tangkapan nelayan tidak dipadukan dengan jenis cenderamata yang lain. Wisatawan masih susah menemukan fasilitas pariwisata di lokasi sekitar Pantai Wonokerto.

3. Kelembagaan Pengelola Aksesibilitas Aksesibilitas menuju obyek wisata sudah tersedia jalan beraspal, hanya kondisinya yang masih terlihat mengalami kerusakan pada beberapa bagian jalan. Jalan tersebut merupakan jalan kabupaten, sehingga pemerintah daerah melalui Dinas Pekerjaan Umum (DPU) bertanggungjawab dalam pengelolaan jalan tersebut. Namun setelah pembangunan jalan dilakukan, perawatan jalan yang mengalami kerusakan masih belum dilakukan oleh pemerintah kabupaten. Masyarakat melalui pemerintah desa dan kecamatan

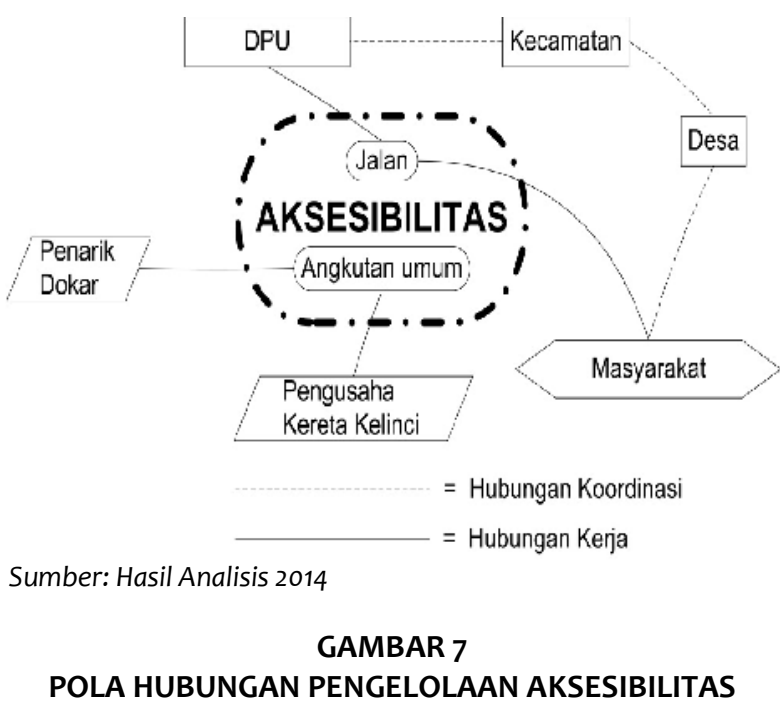

sudah meminta Pemerintah Kabupaten untuk melakukan perbaikan. Tetapi masih belum membuahkan hasil. Sehingga pada beberapa bagian jalan dilakukan perbaikan oleh masyarakat secara swadana.

Transportasi menuju obyek wisata untuk sementara hanya bisa dilakukan dengan kendaraan pribadi. Angkutan umum yang memiliki trayek khusus menuju lokasi wisata tidak tersedia. Sarana angkutan umum yang tersedia hanya berupa dokar dan kereta kelinci, namun dapat disewa oleh wisatawan untuk menuju ke lokasi wisata. Sehingga tidak ada trayek khusus terhadap angkutan umum tersebut. Pengelolaan terhadap angkutan tersebut masih dilakukan sendiri-sendiri oleh swasta. Sehingga aksesibilitas wisatawan untuk menuju kawasan wisata terkesan seadanya tanpa pengelolaan yang baik.

4. Kelembagaan Pengelola Promosi

Pengelolaan terhadap promosi oleh Pemerintah Kabupaten guna mendukung pengembangan pariwisata pesisir pantai Wonokerto masih minim dilakukan. Salah satu bentuk promosi yang sudah dilakukan adalah hanya dengan membuat papan petunjuk arah kepada wisatawan untuk menuju lokasi wisata yang terletak di jalan lintas pantai utara. Sehingga informasi kepada wisatawan masih sangat kurang. Upaya promosi yang lain adalah oleh wisatawan itu sendiri. Pengalaman menyenangkan yang didapatkan selama beraktifitas wisata kemudian menyebar ke masyarakat lain. Sehingga lokasi wisata yang didatangi tersebut lebih dikenal oleh masyarakat luas.Promosi secara verbal juga dilakukan oleh Pegawai Dinas, Kecamatan, Desa dan TPI tentang pelaksanaan nyadran dan syawalan. 
Pada pergelaran acara nyadran dan syawalan yang memang sudah rutin dilaksanakan, maka

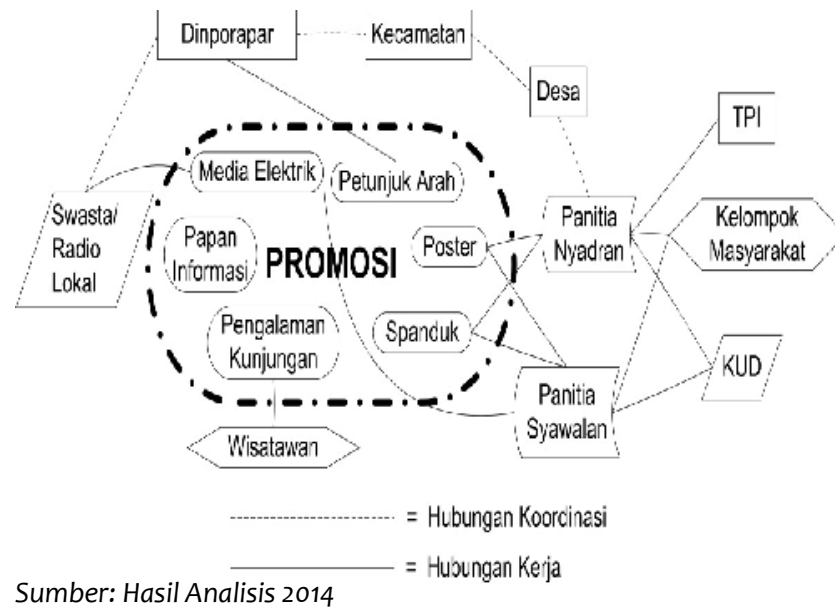

GAMBAR 8

POLA HUBUNGAN PENGELOLAAN PROMOSI upaya promosi pada moment tersebut sudah dilakukan dengan lebih baik. Promosi dilakukan oleh pelaksana nyadran dan syawalan yang merupakan kelompok masyarakat yang dibentuk sebagai penyandang dana sekaligus panitia pelaksana. Upaya promosi dilakukan dengan membuat spanduk besar di tempat-tempat keramaian seperti Pasar Wiradesa. Selain itu juga dilakukan penyebaran pamflet/poster di jalan-jalan raya. Media elektronik seperti stasiun radio juga sudah digunakan sebagai sarana promosi jika akan mendatangkan artis ibukota. Seperti Radio Damashinta dan Radio Kota Batik. Sehingga dalam pengelolaan promosi dan informasi masih terkesan tidak maksimal.

\section{Analisis Pengembangan Kelembagaan Pariwisata Pantai Wonokerto dengan Prinsip} Kelembagaan yang Berkelanjutan

Berdasarkan analisis sebelumnya dapat dipastikan bahwa stakeholders yang ada di Kawasan Pesisir Pantai Wonokerto mempunyai kontribusi terhadap pengembangan kawasan tersebut berdasarkan peranannya. Pengembangan pariwisata pesisir Pantai Wonokerto merupakan suatu usaha yang sangat kompleks yang melibatkan banyak sektor. Sehingga dalam penentuan pengelola kelembagaannya harus melibatkan berbagai pihak/stakeholder. Apabila setiap stakeholder merasa terlibat dan mendapatkan manfaat maka kelembagaan akan berjalan dengan baik dan efektif. Pelibatan berbagai pihak tersebut juga harus didukung dengan tingginya tingkat kepercayaan masing-masing stakeholder, sehingga hubungan antar pihak dapat berjalan harmonis dan berkesinambungan. Salah satu indikator kelembagaan yang berkelanjutan adalah dengan terciptanya Koordinasi, Integrasi, Simplifikasi, Sinkronisasi dan Mekanisasi diantara para pemangku kepentingan.

1. Koordinasi

Koordinasi didefinisikan sebagai proses penyatuan tujuan masing-masing stakeholders dalam rangka mencapai tujuan bersama. Koordinasi merupakan suatu kata yang mudah diucapkan namun sangat sulit untuk dilaksanakan, bahkan di negara yang sudah maju sekalipun. Terkait dengan pengembangan pariwisata Pantai Wonokerto, koordinasi selama ini masih berjalan secara parsial. Koordinasi seharusnya dilakukan mulai dari tahap perencanaan, pelaksanaan dan monitoring dengan melibatkan seluruh stakeholders yang terkait. Seperti halnya dalam penyusunan Dokumen Masterplan Khusus Pariwisata Kawasan Wonokerto, apabila semua stakeholder diikutsertakan mulai dari tahap perencanaan, maka tidak akan terjadi kendala dalam pelaksanaannya. Konflik kepentingan dengan masyarakat dapat dihindari apabila dari awal perencanaan sudah ada komunikasi dengan masyarakat.

2. Integrasi

Integrasi berasal dari bahasa Inggris "Integration" yang berarti kesempurnaan atau keseluruhan. Integrasi dapat dimaknai sebagai proses penyesuaian berbagai permasalahan 
yang berkaitan dengan pengembangan pariwisata Pantai Wonokerto sehingga tercapai keserasian fungsi masing-masing stakeholders. Integrasi lebih cenderung kepada penyatuan rencana tindak tentang pengembangan pariwisata Pantai Wonokerto, dengan tetap menyesuaikan tugas pokok masing-masing. Integrasi dilaksanakan agar tidak terjadi kesalahpahaman dan konflik yang diakibatkan oleh ego sektoral dalam pengembangan pariwisata Pantai Wonokerto. Potensi pariwisata di Pantai Wonokerto selain pantai, adanya dermaga, TPI (tempat pelelangan ikan), mangrove, kebun melati dan perkampungan nelayan menambah daya tarik tersendiri kawasan tersebut. Masing-masing stakeholder memiliki kepentingan tersendiri terhadap potensi yang ada. Oleh karena itu, perlu adanya integrasi atraksi tersebut dalam suatu kawasan yang terpadu. Sehingga dapat meminimalisir konflik dalam pemanfaatannya.

3. Simplifikasi

Pengertian simplikasi adalah makna realitas yang sangat tergantung pada pemaknaan suatu masalah secara lebih sederhana, dengan pola pikir yang diterapkan untuk memahami sesuatu permasalahan. Simplikasi adalah segala usaha untuk melakukan penyederhanaan organisasi dalam bentuk penyederhanaan cara kerja guna efisiensi tenaga, waktu dan biaya, sehingga tercapai tujuan yang telah direncanakan. Dalam pengembangan pariwisata Pantai Wonokerto melibatkan berbagai macam stakeholders dalam pengelolaan atraksi, amenity, aksesibilitas dan promosi. Dalam pengelolaan atraksi saja sudah banyak stakeholder yang terlibat dan mempunyai tujuan masing-masing. Belum komponen pariwisata yang lain. Oleh karena itu diperlukan simplifikasi dalam pengorganisasiannya. Misalnya dengan membentuk suatu kelembagaan kolaboratif yang dapat menampung semua kepentingan stakeholders yang ada, baik dalam hal atraksi, amenity, aksesibilitas maupun promosiny. Sehingga program-program pengembangan pariwisata Pantai Wonokerto dapat dilakukan secara terpadu.

4. Sinkronisasi

Sinkronisasi adalah proses penyamaan data antara stakeholders yang dilakukan secara berkala dan terencana. Sinkronisasi diperlukan untuk menghindari terjadinya ketidak konsistenan data akibat adanya akses data yang tidak valid. Selain itu, sinkronisasi juga merupakan suatu usaha untuk menyesuaikan/menyelaraskan tindakan-tindakan dari berbagai stakeholderssehingga di dapat keserasian. Sinkronisasi dilakukan antara aspek perencanaan dengan pelaksanaan yang dilakukan oleh masing-masing stakeholder dalam pengembangan pariwisata Pantai Wonokerto. Sinkronisasi dilakukan terhadap programprogram yang akan dilaksanakan oleh setiap stakeholders di kawasan tersebut. Selain itu juga diperlukan adanya sinkronisasi dalam pemanfaatan anggaran setiap program. Sehingga program-program dan penganggarannya tidak terjadi tumpang tindih atau terjadi gap yang akan menimbulkan permasalahan baru.

5. Mekanisasi

Mekanisasi dalam pengembangan pariwisata Pantai Wonokerto adalah mengaplikasian prinsip ilmu dan teknologi pariwisata dalam pengelolaan, pengendalian dan evaluasi. Melibatkan sistem dan manajemen serta sarana prasarana yang ada. Mekanisasi pariwisata harus melibatkan semua perangkat dan peralatan yang membantu dalam menjalankan aktivitas pariwisata. Mekanisasi merupakan langkah-langkah nyata yang dilakukan berdasarkan teori dan teknologi sertasarana dan prasarana yang ada agar tujuan pengembangan pariwisata Pantai Wonokerto dapat tercapai. Misalnya menambah daya tarik dari atraksi yang ada, meningkatkan pelayanan (amenity) kepada wisatawan, 
memperbaiki sistem aksesibilitas yang ada dan melakukan upaya-upaya promosi yang lebih kreatif agar mengundang wisatawan untuk berkunjung ke lokasi wisata.

\section{KESIMPULAN}

Stakeholder pengelolaan atraksi berupa keindahan pantai, keberadaan mangrove, tambak, dermaga, TPI dan perkampungan nelayan yang ada di pesisir Pantai Wonokerto adalah Pemerintah Daerah, swasta dan masyarakat nelayan. Pada pengelolaan amenity, berupa ketersediaan rumah makan, penginapan, biro perjalanan, toko souvenir dilakukan oleh swasta, masyarakat umum. Aksesibilitas berupa jalan menuju lokasi wisata sudah di bangun oleh pemerintah dengan kondisi mulai rusak. Sarana transportasi berupa angkutan umum atau rental kendaraan di obyek wisata maupun sarana transportasi pendukung berupa bengkel atau pengisian bahan bakar juga sudah dikelola oleh swasta dan pemerintah daerah. Promosi dan informasi usaha pengembangan pariwisata yang sudah dilakukan oleh pemerintah, swasta dan lembaga masyarakat, serta wisatawan itu sendiri.

Berdasarkan hal tersebut di atas dapat dilihat bahwa masing-masing stakeholders sudah mengambil peran dalam pengembangan pariwisata pesisir Pantai Wonokerto. Baik itu stakeholders pemerintah, swasta, lembaga masyarakat maupun masyarakat itu sendiri. Apabila kita telisik, masing-masing program dan kegiatan dari stakeholders membawa dampak positif terhadap pengembangan pariwisata pesisir Pantai Wonokerto. Namun pengelolaan pariwisata pesisir Pantai Wonokerto masih dilakukan sendiri-sendiri sesuai kepentingan dan pengaruh masing-masing stakeholder. Berdasarkan hasil penelitian, tidak ditemukan kelembagaan formal dalam pengembangan pariwisata pesisir Pantai Wonokerto. Sehingga agar pengembangan kelembagaan pengelola dapat berkelanjutan diperlukan koordinasi antar stakeholder untuk mencapai tujuan bersama. Selain itu juga harus diintegrasikan setiap kegiatan/program agar tidak terjadi tumpang tindih atau terjadi gap. Kelembagaan pengelola juga perlu dilakukan simplifikasi dengan membentuk suatu kelembagaan kolaboratif yang dapat menampung aspirasi dan kepentingan semua stakeholders. Sinkronisasi data-data antara stakeholders juga harus dilakukan secara berkala dan terencana. Sinkronisasi diperlukan untuk menghindari terjadinya ketidak konsistenan data akibat adanya akses data yang tidak valid. Mekanisasi juga diperlukan untuk menambah daya tarik wisata, pelayanan terhadap wisatawan, kemudahan aksesibilitas dan kreatifitas dalam upaya promosi.

\section{DAFTAR PUSTAKA}

Aulia, Tia Oktaviani Sumarna. 2010. Kearifan Lokal dalam Pengelolaan Sumberdaya Air di Kampung Kuta. Bogor: Institut Pertanian Bogor.

Bengen, Dietriech G. 2002. Pengembangan Konsep Daya Dukung dalam Pengelolaan Lingkungan Pulau-Pulau Kecil. Kantor Menteri Negara Lingkungan Hidup RI dan FPIK Institut Pertanian Bogor.

Damanik, J dan HF. Weber. 2006. Perencanaan Ekowisata: Dari Teori ke Aplikasi. Yogyakarta: Penerbit Andi.

Djogo, T, Sunaryo, D. Suharjito, dan M. Sirait. 2003. Kelembagaan dan Kebijakan dalam Pengembangan Agroforestri. World Agroforestry Centre (ICRAF). Bogor.

Gunn, C. A. 1993. Tourism Planning: Basics, Concepts, Cases. USA: Taylor \& Francis. 
Mikkelsen, B. 2003. Metode Penelitian Parstisipatoris dan Upaya-upaya Pemberdayaan. Sebuah Buku Pegangan Bagi Para Praktisi Lapang. Penerjemah. Jakarta: Matheos Nalle-Ed.3. terjemahan dari : Methods for Development Work and Research : A Guide for Practitioners.

Nazir, Moh. 1988. Metode Penelitian. Jakarta: Ghalia Indonesia.

Peraturan Daerah No. 11 Tahun 2008 tentang Retribusi Tempat Rekreasi dan Olah Raga.

Peraturan Daerah No. 16 tahun 2009 tentang Rencana Pengelolaan Wilayah Pesisir.

Peraturan Daerah No. 17 tahun 2009 tentang Rencana Zonasi Wilayah Pesisir.

Spillane, J James. 1994. Ekonomi Pariwisata, Sejarah Dan Prospeknya. Yogyakarta: Kanisius.

Siregar, M. 2011. "Peranan Stakeholders terhadap Pengembangan Ekowisata di Taman Nasional Teluk Cenderawasih Kabupaten Teluk Wondama Provinsi Papua Barat". Tugas Akhir tidak diterbitkan, Sekolah Pascasarjana, Institut Pertanian Bogor, Bogor.

Sugiyono. 2009. Metode Penelitian Kuantitatif Kualitatif dan R\&D. Jakarta: CV. Alfabeta.

Undang Undang Nomor 27 Tahun 2007 Tentang Pengelolaan Wilayah Pesisir dan Pulau-pulau Kecil.

Wahab S. 1992. Manajemen Kepariwisataan. Jakarta: PT. Pradnya Paramita.

Yin, Robert K. 2003. Studi Kasus: Disain dan Metode. M. Djauzi Mudjakir (Penerjemah). Jakarta: PT. Raja Grafindo Persada. 